\title{
Os contextos do saber: representações, comunidade e cultura
}

JOVCHELOVITCH, Sandra. Os contextos do saber: representações, comunidade e cultura. Petrópolis: Vozes, 2008.

\section{Ariane Franco Lopes da Silva}

Assistente Doutora do Programa de Mestrado em Educação, Universidade Católica de Santos (Unisantos), Santos, SP - Brasil

Na obra Os contextos do saber: representações, comunidade e cultura, Sandra Jovchelovitch faz uma detalhada análise do conceito de representação e apresenta uma marcante contribuição para o entendimento da Teoria das Representações Sociais. Ela parte da análise do problema do conhecimento, que durante muito tempo foi identificado como pertencente ao domínio da racionalidade e da impessoalidade, para desenvolver uma reflexão em torno das dimensões subjetivas, emocionais e relacionais dos saberes. Considerando a herança cartesiana de nossa forma de ver o mundo, que concebe o saber como racionalidade pura, a autora recupera os laços que ligam os conhecimentos às pessoas e às comunidades. Para tal, ela demonstra, de maneira articulada e dinâmica, como as representações estão na base de todos os saberes e como elas têm pouco do impessoal. Com uma narrativa elegante, a autora volta ao problema do 
conhecimento e procura focar o sujeito do saber em sua cultura. Sandra Jovchelovitch lembra que representar não se constitui em um ato solitário de se reproduzir o mundo; muito pelo contrário, ela destaca as características dialógicas das representações, produzidas pelas inter-relações eu/ outro/objeto-mundo. A autora reafirma o caráter simbólico e social das representações, que são por um lado sociais, pois implicam a participação de outros em sua construção; e, por outro, simbólicas, pois utilizam signos arbitrários para darem sentido ao mundo.

No primeiro capítulo, Jovchelovitch recupera os trabalhos de Piaget, Vygotsky e Winnicott sobre a ontogênese da representação, o que facilita o entendimento dos processos simbólicos e genéticos implícitos no seu desenvolvimento. Ela salienta, ainda, que o desenvolvimento das representações se tece na dinâmica afetiva das relações eu e outro. Ao longo do capítulo, a autora discorre sobre a filosofia de Descartes e vemos a preocupação em vincular a formação das representações com os contextos sociais, políticos e históricos, contrapondo a concepção de conhecimento produzida pelo modelo cartesiano, que separou o sujeito do seu mundo. Os efeitos para a psicologia social desse modelo cartesiano são acentuados na explanação que ela faz sobre a separação entre conhecimento e contexto. A autora finaliza o capítulo ao afirmar que as representações são construções de atores sociais, e que elas expressam os diálogos entre mundos internos e externos, entre indivíduos e as coletividades às quais eles pertencem. A autora lembra também que, por serem construções humanas, dependentes de contextos sociais, políticos e históricos, ou seja, constructos psicossociais, as representações nunca captam totalmente a realidade, sendo preciso fazer a distinção entre uma representação e o objeto.

No segundo capítulo, a autora levanta a questão das diferentes formas do saber e como elas se transformam. Quando apresenta a Teoria das Representações Sociais, idealizada por Serge Moscovici, como uma teoria sobre saberes sociais, Jovchelovitch não deixa de ressaltar que ela deve ser compreendida também como uma teoria sobre a elaboração de novos saberes e sobre como eles são assimilados pela sociedade. Ela 
destaca, então, o papel dos inovadores, das minorias, dos que desafiam as práticas tradicionais, ou seja, foca o papel do sujeito individual na criação de representações. Ainda nesse capítulo, a autora menciona o poder das representações em expressar a realidade de uma comunidade, que não é homogênea, tão pouco simples. Jovchelovitch descreve os principais autores que inspiraram Moscovici na construção de sua psicologia social dos saberes e situa a Teoria das Representações Sociais em relação aos trabalhos de Durkheim, Lévy-Bruhl, Piaget, Vygotsky e Freud.

No terceiro capítulo, a autora explana sobre a comunidade como sendo uma unidade de análise e a caracteriza como um espaço intermediário entre a família e a sociedade mais ampla. Ela lembra que somente a coordenação de ações e de diferentes perspectivas dos indivíduos permite a convivência em comum nas comunidades. Apoiandose nos pensamentos de Freud, para quem uma comunidade só se torna possível quando as forças de poder e de agressão do indivíduo forem amortecidas pelos laços de identificação, amor e solidariedade, Jovchelovitch mostra que, nos processos de formação das comunidades, interações entre o mesmo e o outro nem sempre são harmônicas. As tensões originadas desses encontros são comuns, pois nem sempre se chega a consensos e inclusões. Contudo, é a partir dessas tensões que as pessoas se identificam e são reconhecidas como pertencentes a uma mesma comunidade. Mais adiante no capítulo, a autora disserta sobre a formação de fronteiras das comunidades por meio de ações relacionais. Por um lado as comunidades são construídas por aqueles que se identificam como pertencentes a ela; e, por outro, por aqueles que estão fora de suas fronteiras. Ou seja, as percepções que temos dos outros, as expectativas a seu respeito, definem, tanto quanto o eu coletivo, a construção dessa comunidade e sua identidade cultural. A autora salienta, ainda, que a análise dessa questão é necessária, pois a formação de fronteiras revela como as identidades e os modos de vida das comunidades se desenvolvem com o tempo.

A autora introduz, a seguir, o tema dos saberes comuns de uma comunidade. Esses saberes fornecem os fundamentos, as referências, 
os conhecimentos e os sentidos necessários para a vida em grupo e têm como função assegurar a sua unidade. Segundo Jovchelovitch, seu estudo permite a compreensão de como as comunidades se constituem e se mantêm coesas. Ela defende que a vida em comum tem um duplo caráter: o dado, expresso pelo saber comum; e, ao mesmo tempo, o renovado, ou seja, o caráter de ser construído pelos atores sociais. Dando continuidade ao tema, a autora apresenta a questão da memória social como o fator que desempenha um importante papel na manutenção, tanto das semelhanças e permanências quanto das diferenças e mudanças nas comunidades. A fim de discutir a memória social, Jovchelovitch faz uma exposição dos trabalhos de Halbwachs, para quem as memórias individuais são na verdade memórias do grupo. A autora expõe também os trabalhos de Bartlett sobre as influências sociais tanto no processo quanto no conteúdo das memórias. Assim, Jovchelovitch reflete sobre a relevância dos referenciais sociais do passado para a compreensão do presente, o que assegura o equilíbrio entre as permanências e as mudanças. Ao apresentar o tema das esferas públicas, como espaços comuns aos membros das comunidades que permitem a discussão de temas de interesse, dando visibilidade à vida comunitária, Jovchelovitch examina a contribuição de Hannah Arendt e de Habermas para esse debate. Ela lembra, ainda, que as esferas públicas não são idênticas e podem assumir formas diversas. Compreendê-las se constitui, então, em uma importante ferramenta para compreender a própria comunidade.

O capítulo 4 apresenta as diferentes formas e funções dos saberes e aprofunda as colocações feitas anteriormente sobre as relações eu-outro-objeto como formadores da arquitetura da representação e da comunidade. Esse capítulo investiga os constituintes do processo representacional, e discute o "quem", o "como", o "o quê" o "por quê", e o "para quê" dos saberes. Após essa discussão, encontramos nesse capítulo um momento em que a autora diferencia as representações sociais das representações coletivas ao introduzir o tópico "modalidades de representação". As representações sociais, ao contrário das coletivas, são produzidas em contextos não tradicionais, em que as comunidades 
enfrentam a diversidade. Os atores sociais são forçados a lidar com alternativas, com a pluralidade de perspectivas, produzindo campos de representações que embarcam o novo, o diferente. Por fim, a autora lembra que as representações sociais lidam com o novo e se apropriam dele por meio dos processos de ancoragem e objetivação. Encontramos nesse capítulo, também, uma discussão sobre as funções do mito, da crença, da ideologia, além de uma reflexão sobre a diferença entre ciência e senso comum.

No capítulo 5, a partir da análise da ambivalência das relações eu e outro, a autora afirma que diferentes formas de saber podem coexistir. Para Jovchelovitch, o reconhecimento do outro implica o reconhecimento da legitimidade do conhecimento do outro. Essa análise dá lugar a uma exploração dos tipos de encontros de saberes, que ela denomina de dialógicos e não dialógicos. Discute, então, os processos de classificação, segregação e exclusão originados dos encontros não dialógicos e dedica a última parte do capítulo ao método de alfabetização de Paulo Freire, como ilustrativo de um modelo exemplar de um encontro dialógico entre diferentes sistemas de conhecimento.

O capítulo 6 examina a ideia de que todos os conhecimentos são expressivos, representando mundos subjetivos, intersubjetivos e objetivos e que diferentes formas de saber podem coexistir. Prepara-se, assim, o caminho para argumentar que as representações sociais permitem investigar como uma comunidade constrói saberes, como as identidades estão vinculadas a esses saberes e como eles expressam culturas e modos de vida. Ao final do capítulo, a autora reflete sobre tópicos ligados à participação comunitária e ao empoderamento e discute como a intervenção de pesquisadores, que mapearam as representações de determinada comunidade, podem atuar de forma a promover a mudança social.

Quando discute as tradições culturais de uma comunidade e formas heterogêneas de conhecimentos, sugerindo que existe coexistência de saberes, sua obra nos permite refletir acerca das questões emergentes no campo da educação. Qual seria o papel da escola em um cenário contemporâneo multifacetado, multicultural e globalizado? Como integrar 
a todos respeitando as diferenças? O entendimento dessas questões fica facilitado com essa leitura, pois a autora demonstra como mudanças nas representações implicam mudanças nas culturas.

Recebido: 04/08/2010

Received: 08/04/2010

Aprovado: 08/11/2010

Approved: 11/08/2010 